\title{
MORPHOHISTOLOGICAL STUDIES OF THE GONADS OF HYBRID POLYPLOID LOACH COBITIS FROM THE LOWER DNIESTER
}

\author{
Nina Fulga, Laurenţia Ungureanu, Dumitru Bulat, Denis Bulat, Ion Toderas, \\ Anatol Marta
}

Institute of Zoology, Chisinau, Republic of Moldova e-mail: fulganina@yahoo.com

\begin{abstract}
In the lower Dniester, polyploid females of the hybrid complex Cobitis taenia are a portion spawning species with asynchronous development of germ cells during the entire breeding period. The spawning season in this water basin begins in the second decade of May and ends in July. In the population, in parallel with females, hermaphrodite individuals are also present, in which the ovary zone is functional, and the testis zone is sterile. A decrease in the relative mass of the gonads of subsequent generations was noted, which leads to a consistent decrease in the value of the gonadosomatic index, in females, before the second and third spawning.
\end{abstract}

\section{Introduction}

In the genus Cobitis (Cobitidae), inhabitants of rivers and water bodies of Eurasia, along with bisexual diploid species, clonal forms were found, represented, as a rule, by triploid females [1]. To date, about 85 forms have been found among fish, which are represented only by females that reproduce by gynogenesis. In natural gynogenesis, males are needed, whose sperm stimulate the development of eggs, while true fertilization does not occur. In this regard, gynogenetic forms of fish live together with one or two closely related bisexual species, as a result of hybridization of which they arose [12]. In rare cases, clonal forms for their reproduction use males of the third less closely related bisexual species. Thus, the gynogenesis of clonal forms leads to the emergence of unisexual-bisexual (clonal-bisexual) complexes.

In this study, the ovarian histology of hybrid polyploid loach of the $C$. taenia complex of the lower Dniester during the reproductive cycle was investigated.

\section{Material and methods}

The collection of ichthyological material was carried out in 2020 from the lower Dniester during the pre-spawning and spawning periods from April to May. The collected material was processed in accordance with the methods generally accepted in ichthyology and fish ecology [4]. All caught females of Cobitis tanaitica in the amount of 37 individuals were subjected to general biological analysis with the determination of linear mass indicators, gonadosomatic index (GSI). For histological studies, gonadal samples were fixed in $4 \%$ formalin, followed by histological processing according to the generally accepted method. Sections $7 \mu \mathrm{m}$ thick were stained by the Mallory method [6]. The stages of maturity of the gonads were determined according to the standard recommendations [6], and the degree of development of oocytes according to the classification of Kazansky [2]. The gonadosomatic index was calculated as the ratio of the mass of the gonads to the mass of the body without viscera in percent. Oocytes, in 
the phase of complete vitellogenesis, were measured with an eyepiece micrometer. All digital data were processed statistically [3]. Microphotographs were made using a microscope Lomo, Mikmed-2 with a video camera.

\section{Results and discussions}

Since during the entire spring-summer season, only females and hermaphrodites of Cobitis taenia were caught in the catches, it can be assumed that in the lower Dniester, the fish reproduce gynogenetically and produce triploid eggs, which are stimulated to develop sperm by Cobitis males [11]. The length and body weight of sexually mature females ranges from 6.8 to $9.2 \mathrm{~cm}$ and from 2.19 to $6.76 \mathrm{~g}$, respectively.

In the pre-spawning period, in April at water temperature of $120 \mathrm{C}$, the control catches included hermaphrodite individuals and females with gonads at maturity stage IV with older generation oocytes in the phase of intense vitellogenesis. Their diameter corresponded to $861.33 \pm$ $4.76 \mu \mathrm{m}$. The ovaries of hermaphrodites are also at the IV stage of maturity and contain yolk eggs with a diameter of $857.60 \pm 7.01$ microns, and the testicles contain seminal ampoules along the periphery of which cysts with spermatogonia and spermatocytes are located. These individuals have one gonad, but the zones of the ovary and testis were always limited and no signs of the transition of the testis to the ovary were found (fig. 1). In the testis zone, signs of degeneration are observed, expressed in the formation of pyknotic cells. Similar signs of destructive changes in the development of testes were also noted among the diploid hybrid males of C.elongatoides and C. taenia [8], as well as in tetraploid Cobitis individuals [9]. As the authors point out, the first signs of degeneration (cell pyknosis) appear in spermatocytes. In the family Cobitidae, cases of hermaphroditism have been reported [10]. Also, the presence in one gonad of the hermaphrodite zone of the ovary and the zone of the testis, separated from each other was noted.

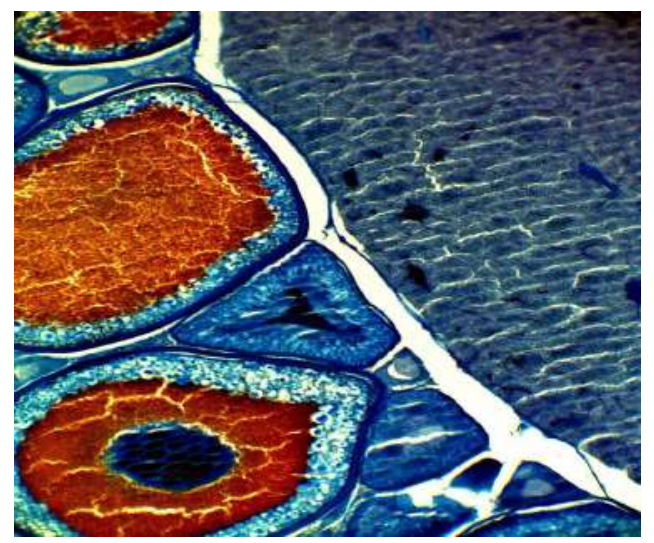

Figure 1. Fragment of hermaphrodite gonad

With a slight difference in body length and weight, the average value of GSI in hermaphrodites is slightly higher than in females during this period, but their difference in values is not significant $\mathrm{P} \leq 0.95$ (tab.1).

The spawning season for the loach in the lower Dniester begins in the second decade of 
May at a water temperature of 140C. During the spawning period, the ovaries of some females were at the IV-V stage of maturity, with oocytes of the older generation in the maturation phase, with the diameter of $1056.0 \pm 19.67$. As the temperature of the water in the Dniester rises, the amount of food consumed by the fish increases, which contributes to an increase in oocyte size and ovarian weight.

During the research period, the catches also contained spawning females with gonads at maturity stages VI-IV2, as evidenced by the presence of empty follicular membranes and oocytes in the phases of intense vitellogenesis, the beginning of yolk accumulation and vacuolization. From the data given in the table, it can be seen that a higher GSI value in females is observed before the first spawning, while in individuals before the second and third spawning, this indicator decreases (tab.1).

Table 1. Biological characteristics of the loach from lower Dniester

\begin{tabular}{|c|c|c|c|c|c|}
\hline $\begin{array}{l}\text { Period, } \\
\text { month }\end{array}$ & Sex & $\begin{array}{c}\text { Maturity } \\
\text { stage }\end{array}$ & $\begin{array}{l}\text { Body length, } \\
\mathrm{cm}\end{array}$ & $\begin{array}{c}\text { Body } \\
\text { weight, } g\end{array}$ & GSI\% \\
\hline \multirow{2}{*}{$\begin{array}{l}\text { IIIrd decade } \\
\text { of April }\end{array}$} & Females & IV & $7,62 \pm 0,31$ & $3,36 \pm 0,33$ & $9,00 \pm 1,18$ \\
\hline & Hermaphrodites & IV & $7,95 \pm 0,34$ & $3,53 \pm 0,51$ & $12,31 \pm 1,21$ \\
\hline \multirow{2}{*}{$\begin{array}{c}\text { IInd decade } \\
\text { of May }\end{array}$} & Females & IV-V & $9,20 \pm 0,41$ & $6,76 \pm 0,39$ & $29,19 \pm 1,84$ \\
\hline & Females & $\mathrm{VI}^{-I V_{2}}$ & $7,0 \pm 0,28$ & $2,85 \pm 0,17$ & $7,88 \pm 1,59$ \\
\hline \multirow{2}{*}{$\begin{array}{c}\text { Ist decade of } \\
\text { June }\end{array}$} & Females & $\mathrm{V}_{2}-\mathrm{VI}$ & $7,93 \pm 0,57$ & $3,28 \pm 0,63$ & $10,95 \pm 1,12$ \\
\hline & Females & $\mathrm{IV}_{2}-\mathrm{V}$ & $8,03 \pm 0,25$ & $3,19 \pm 0,18$ & $23,76 \pm 2,03$ \\
\hline \multirow{3}{*}{$\begin{array}{l}\text { Ist decade of } \\
\text { July }\end{array}$} & Females & $\mathrm{V}_{3}-\mathrm{VI}$ & $7,25 \pm 0,29$ & $2,91 \pm 0,19$ & $7,25 \pm 1,57$ \\
\hline & Females & $\mathrm{IV}_{3}-\mathrm{V}$ & $7,30 \pm 0,23$ & $3,21 \pm 0,34$ & $15,41 \pm 1,23$ \\
\hline & Hermaphrodites & VI -III & $6,8 \pm 0,21$ & $2,19 \pm 0,14$ & $9,04 \pm 1,34$ \\
\hline
\end{tabular}

After the spawning of the first portion of eggs, the ovaries contain, along with empty follicular membranes, oocytes at different phases of the period of trophoplasmic growth, which indicates the asynchronous nature of their development. In early June, before the second spawning in the season, the second generation of oocytes completes the accumulation of yolk and passes into the maturation phase, and their gonads at the IV2-V stage of maturity. By this time, some of the females have already spawned a second time. The onset of ovulation of mature germ cells of the second generation occur in the first decade of June, with a thermal regime of the lower Dniester of $170 \mathrm{C}$.

The gonads of females caught in the first ten days of July have the maturity stages IV3-V. The water temperature during this period does not exceed 180C. Among the caught fish, a hermaphrodite specimen was found, laying eggs, with an ovary at the VI -III stage of maturity. This individual has completed the spawning season. After the third spawning, empty follicular membranes remain in the ovary of the hermaphrodite, resorbing oocytes of the next year's generation in the phases of protoplasmic growth, vacuolization, and not spawned yolk oocytes in the process of deep resorption (fig. 2). Such an individual will miss the next spawning season. 


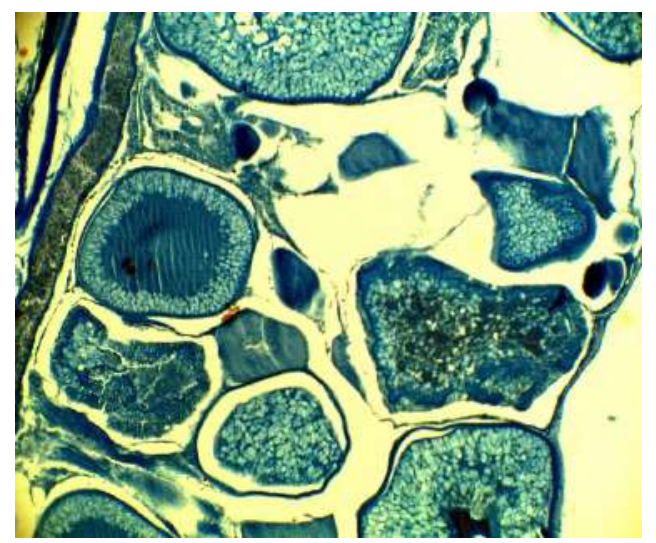

Figure 2. Fragment of hermaphrodite oocyte that has completed the spawning season

It must be noted that the hermaphrodite testes in July, as well as in April, still contain cysts with sexual products in the early stages of spermatogenesis in the process of degeneration, which causes sterility of the seminal tissue (fig. 3). The sterility of the gonads is a consequence of profound disturbances in the development of the reproductive system, which probably appears due to gynogenetic reproduction. For the first time, male sterility was noted in the hybrid fish C. taenia and C. Elongatoides [8]. It is also pointed out that males are heterozygous sex.

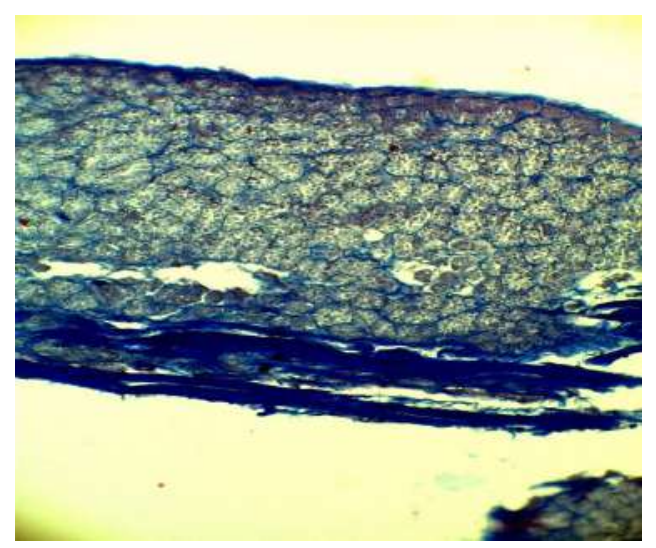

Figure 3. Testes of hermaphrodite in July

Before the third spawning in the spawning season, females with degenerating reproductive cells were identified. On histological preparations, destructive changes in yolk oocytes are expressed in the disappearance of nuclei, fragmentation of the oocyte's own membrane, and partial homogenization of the yolk. Oocytes also underwent resorption in the phases of vitellogenesis, which is accompanied by the absence of cell turgor, fragmentation of the oocyte's membrane, destruction of vacuoles and fusion of their contents into a homogeneous mass, as well as oocytes of the reserve fund in the initial phase of vitellogenesis (fig. 4). 


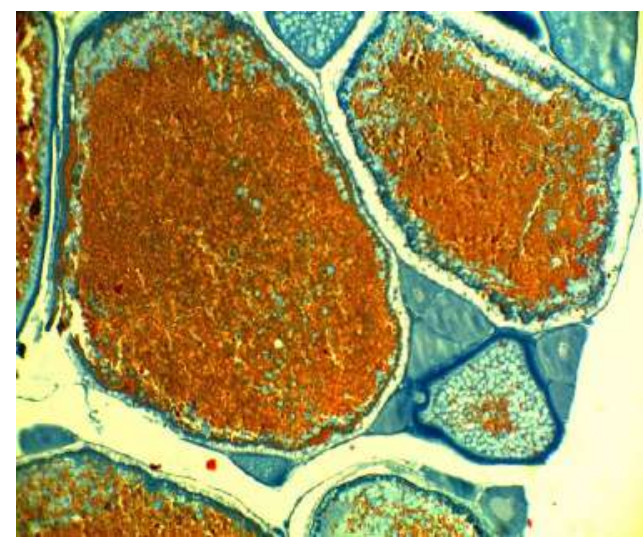

Figure 4. Resorption of yolk in third generation oocytes

According to the studies carried out, it was found that during May-July, at a temperature regime of the lower Dniester within the range of 14-180C, three generations of oocytes are formed and prepared for spawning (tab.1). A similar spawning time, from May to July, was observed in C. taenia from Lake Klavoi, but at a water temperature exceeding 18,50 C [7].

\section{Conclusions}

In the lower Dniester, polyploid females of the hybrid complex Cobitis taenia are a portion spawning species with asynchronous development of germ cells during the entire breeding period. The spawning season in this reservoir begins in the second decade of May and ends in July. In the population, in parallel with females, hermaphrodite individuals are also present, in which the ovary zone is functional, and the testis zone is sterile.

With three portions of spawning in females, a decrease in the relative mass of the gonads of subsequent generations is noted, which leads to a consistent decrease in the value of the gonadosomatic index before the second and third spawning. Lower values of this indicator, after the next spawning, are associated with a decrease in the number of yolk oocytes before spawning of the current generation.

The investigations were carried out within the projects no. 2080009.7007.12 and 20.80009.7007.06.

\section{Bibliography}

1. Васильев В.П. Эволюционная кариология рыб. М.: Наука, 1985. 300 с.

2. Казанский Б.Н. Особенности функции яичников у рыб с порционным икрометанием. Тр. лаб. основ рыбоводства. Ленинград: Изд. АН ССР. 1949. Т. 2, с. 64-121.

3. Лакин Г.Ф. Биометрия. Москва. «Высшая школа» 1980. 291с.

4. Правдин И. Ф. 1966. Руководство по изучению рыб. М: Пищевая промышленность. 1966$376 \mathrm{c}$.

5. Роскин Г.И., Левинсон Л.Б. Микроскопическая техника. Москва: Советская наука. 1957. $487 \mathrm{c}$.

6. Сакун О.Ф., Буцкая Н.Ф. Определение стадий зрелости и изучение половых циклов рыб. 
Мурманск: Изд-во ПИНРО. 1968. 48 с.

7. Ючно Д, Боронь А 2006 Возраст, размножение и плодовитость C. Taenia L из озера Клавой (Польша). Репродуктивная биология Т.6.№2 .C133-148.

8. Juchno D., Boron A. Histological evidence that diploid of C. taenia и C. elongatoides develop into fertile females and sterile males. Poland. Journal Hidrobiologia, 2018, 814:147-159.

9. Juchno, D., A. Pecio, A. Boroń, A. Leska, O. Jabłońska, B. I. Cejko, R. K. Kowalski, S. Judycka \& M. Przybylski, 2017. Evidence of the sterility of allotetraploid Cobitis loaches (Teleostei, Cobitidae) using testes ultrastructure. Journal of Experimental Zoology 327A: 66-74.

10. Maria Berica Rasotto Source 1992.Gonadal differentiation and the mode of sexuality in Cobitis taenia (Teleostei; Cobitidae). American Society of Ichthyologists and Herpetologists (ASIH) Copeia, Vol. 1992, No. 1.pp. 223-228

11. Marta A., Toderaş I.C, Bulat, D.E., Bulat, D.E., Purcic, V.T. Diversitatea speciilor si biotipurilor hibride din genul Cobitis (Teleostei: Cobitidae) din bazinele acvatice ale Republicii Moldova. Buletinul Academiei de Ştiinţe a Moldovei. Ştiinţele vieţii. 2017, nr. 3(333), p.126-131.

12. Rab P., Slavik O. Diploid-triploid-tetraploid complex of the spined loach, genus Cobitis in Psovka Creek: the first evidence of the new species of Cobitis in the ichthyofauna of the Czech Republic. Acta Univ. Carolinae. Biologica. 1996. V. 39. № 3-4. P. 201-214. 